\title{
Load Distribution Influence on the Mechanical State of Reinforcement Concrete Structures of a Port Storage Facility
}

\author{
Michail SAMOFALOV*, Leonas USTINOVIČIUS**, Artūras ŠLAUTERIS**** \\ *Klaipèda University, Bijūnuc 17, LT-91225 Klaipéda, Lithuania, E-mail: michail.samofalov@ku.lt \\ **Bialystok University of Technology, Wiejska 45A, PL-15351 Bialystok, Poland, E-mail: l.uscinowicz@pb.edu.pl \\ ***Klaipéda University, Bijūnu 17, LT-91225 Klaipéda, Lithuania, E-mail: arturas.slauteris@ku.lt \\ cross $^{\text {ref }}$ http://dx.doi.org/10.5755/j01.mech.26.6.25239
}

\section{Introduction}

In seaports, storage facilities are an important stage in logistics (Fig. 1). The existing buildings on a port territory are being reconstructed and new storage areas are being built [1]. When loads of bulk materials are being chosen for the designing a storage facility, maximal loadings are commonly being considered. Therefore, during the usage of storage volumes, many practical situations may arise, when the actions are not exceeding the maximal values, but distribution of bulk materials is not as it was simulated by engineering calculations.

Design codes of East Europe (SNIP and SP in Russia) and West Europe (Eurocodes) consider load combinations [2, 3]. On the base of the statistical data, the combination factor $\psi<1$ is applied. For live loads in the design codes only general instructions are presented, so that combinations of such loads should be selected taking into account a real situation. Since the building has not yet been build, it is obvious that it is need to use the data and experience of monitoring of the operation for analogical structures. Such problems are investigated $[1,4,5]$ by scientific research. In many cases a solution is of a local character.

When the reinforcement for structural members is calculated, in some design algorithms the combinations of internal forces from all loadings are used, but not directly combinations of loads [6]. This assumption allows a reducing of a number for considered combinations, guided by the engineering practice.

In our paper a storage facility of bulk materials at the seaport in Klaipeda (Lithuania, the EU) has been investigated. Bearing walls and foundation plate of the facility is acted by different loadings of a storage product. As practice shows, when a calculation model is being created and extreme combinations of loadings are being selected, the possibility of partial filling of storage sectors for the whole facility often are not being taken into account by architects and structural designers. So, extreme zones on the structure can appear, in which the ultimate state by conditions of the strength or deformation is not satisfied. The selection of operational load distribution cases depends on the technical specifications and experience of a structural designer, because design codes specify only maximal values of loads and set general rules for the performing analysis. The presented investigation allows to compare the results from a more exact analysis with the ones achieved from ordinary design calculations. Such methodology can be used for developing of industrial recommendations for the storage facility design.

This research continues the idea of previously published papers on the investigation of the influence of various practical factors on calculation models, which were created while designing real buildings [7-9].

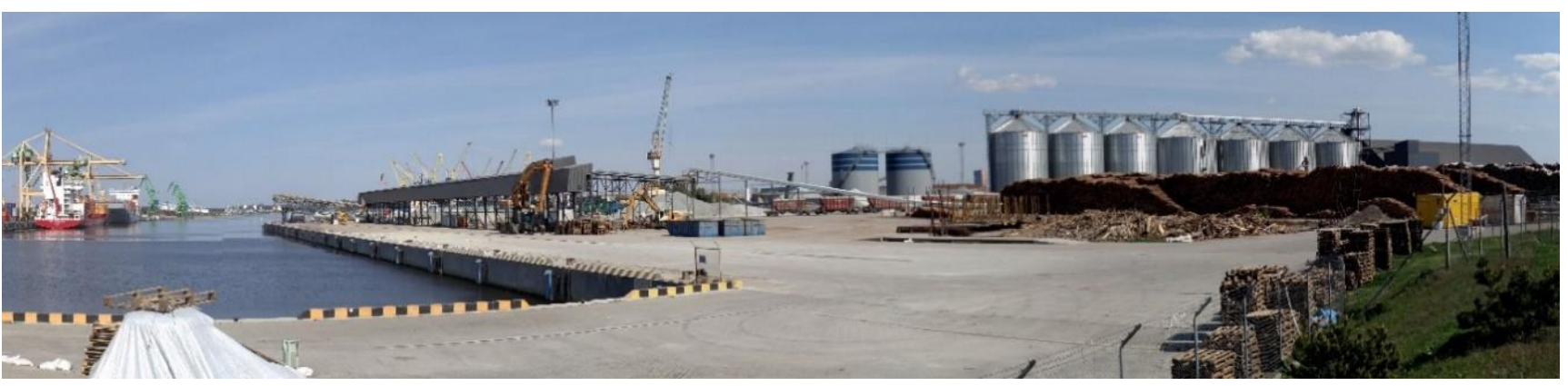

Fig. 1 A view on seaport facilities in Klaipeda (Lithuania, the EU)

\section{Simple calculation model}

For the testing of the load distribution influence, the reinforcement slab of $21 \times 35 \mathrm{~m}$ in plane and of thickness $0.20 \mathrm{~m}$, on reinforcement columns $0.40 \times 0.40 \mathrm{~m}$ of the square cross section, has been considered (Fig. 2). The height of the columns has been defined $5.00 \mathrm{~m}$. Young's modulus of concrete - $30 \mathrm{GPa}$, Poisson's coefficient 0.20 , volumetric weight $-25 \mathrm{kN} / \mathrm{m}^{3}$.

The main assumptions in the analysis of the sim- ple reinforcement slab: the system is statically indeterminate; the self weight is considered as the dead load; the live load is of a long-term character; all bottom supports of columns are rigid; all joints "slab/columns" are rigid.

The spatial model for this simple testing has been created by the finite element method (FEM): the slab from the plate finite elements (FE); columns - from the beam FE. In the slab/columns joints the rigid inserts have been modelled to reduce distortion for internal forces and deformations in joint zones. A regular step of the FE or- 
thogonal grid for the slab in both directions is set $0.200 \mathrm{~m}$. The model is consisted of $18783 \mathrm{FE}$ and 18680 nodes, in total -111936 degrees of freedom. The accuracy of this model is sufficient for our purposes of the testing.

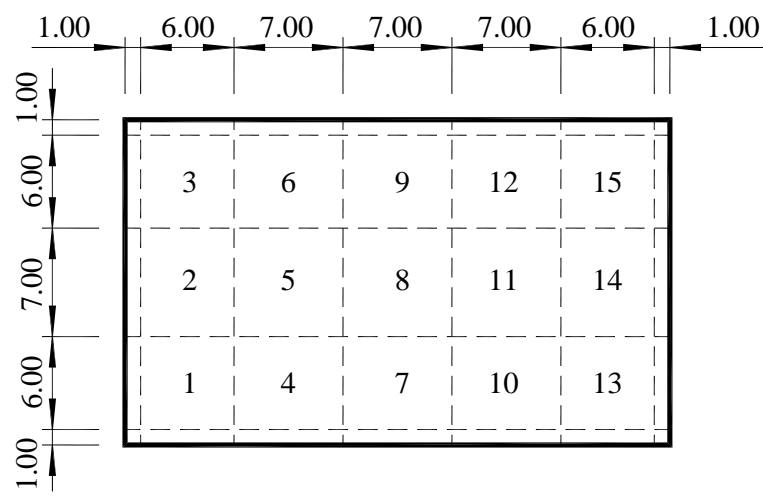

a

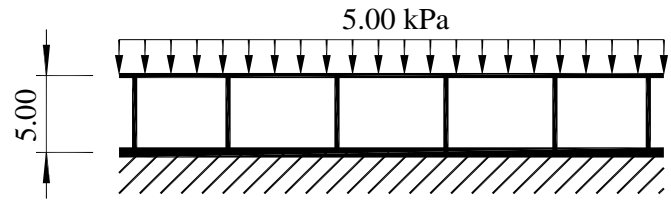

b

Fig. 2 The calculation scheme of the slab during testing: $\mathrm{a}$ - in plane; $\mathrm{b}$ - section

When the calculation scheme was created, the following loads were taken: the structural self weight was defined automatically by software; the live load was accepted $5.00 \mathrm{kPa}$. The safety factor for the self weight 1.35 , for the live load -1.50 . The presented dimensions, cross sections, materials, loads and other parameters of the test model are close to those used by structural designers.

In design practice an ordinary solution case is when whole area of slab is filled by storage product. We denoted this loading as "full". In literature [10, 11] additional distributions by strips are also recommended (Fig. 3). We denote these loadings as "strips". Therefore, the absolutely exact solution is to make all possible $2^{15}=32768$ combinations for all 15 cells. We denoted such a group of loadings as "cells". So, three different cases of design combinations under the following loadings have been considered: i) full; ii) full or by strips; iii) by cells. The results have been received different (Table 1).
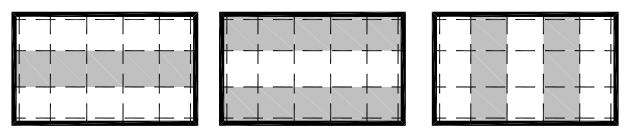

Fig. 3 Load distributions by strips

The reinforcement for the slab was calculated by design requirements for strength and resistance during the cracking [6]. The horizontal reinforcement was defined of class S500, the vertical one - S240. The distance from the slab top surface to the centre of reinforcement was set of $50 \mathrm{~mm}$, the same - at the slab bottom surface. For the cracking calculation depending on diameters of reinforcement bars, in the horizontal direction the diameter of $20 \mathrm{~mm}$ were, for vertical bars $-10 \mathrm{~mm}$. Allowable crack width $0.3 \mathrm{~mm}$ was defined from the design codes.
Table 1

Relative results of the simple model

\begin{tabular}{|c|c|c|c|c|}
\hline \multicolumn{2}{|c|}{$\begin{array}{c}\text { Parameter for } \\
\text { comparison }\end{array}$} & \multicolumn{3}{c|}{ Relative results, when case: } \\
\cline { 2 - 5 } Axial force $N_{x x}$ & $\min$ & 1 & 1.143 & 1.144 \\
\cline { 2 - 5 } & $\max$ & 1 & 1.139 & 1.139 \\
\hline \multirow{2}{*}{ Axial force $N_{y y}$} & $\min$ & 1 & 1.145 & 1.154 \\
\cline { 2 - 5 } & $\max$ & 1 & 1.139 & 1.145 \\
\hline \multirow{2}{*}{ Moment $M_{x x}$} & $\min$ & 1 & 1.000 & 1.080 \\
\cline { 2 - 5 } & $\max$ & 1 & 1.207 & 1.207 \\
\hline \multirow{2}{*}{ Moment $M_{y y}$} & $\min$ & 1 & 1.000 & 1.075 \\
\cline { 2 - 5 } & $\max$ & 1 & 1.182 & 1.183 \\
\hline \multirow{2}{*}{$\begin{array}{c}\text { Moment } M_{x y} \\
\text { Bottom } \\
\text { reinforcement }\end{array}$} & $\min$ & 1 & 1.100 & 1.193 \\
\cline { 2 - 5 } & $\mathrm{max}$ & 1 & 1.100 & 1.193 \\
\cline { 2 - 5 } $\begin{array}{c}\text { Top } \\
\text { reinforcement }\end{array}$ & $Y, \max$ & 1 & 1.194 & 1.228 \\
\cline { 2 - 5 } & $Y, \max$ & 1 & 1.135 & 1.171 \\
\hline $\begin{array}{c}\text { Intensity of } \\
\text { reinforcement }\end{array}$ & $X, \max$ & 1 & 1.000 & 1.079 \\
\cline { 2 - 5 } & $Y, \max$ & 1 & 1.000 & 1.153 \\
\hline
\end{tabular}

The comparison of the calculation results shows, that the usage of strip loadings on the slab and making of appropriate combinations gives a significant increase in some internal forces, sometimes by $20.7 \%$, and - increase of the reinforcements in spans, sometimes by $19.4 \%$. When the most general case "cells" is compared with "full" one, all considered parameters increase. Due to the cracking calculation, the bottom reinforcement in some zones increases up to $22.8 \%$. Of course, only extreme values are presented here, but such comparison partially characterizes the qualitative changes. However, the effect of consideration of combinations is important enough.

A calculation by using a huge number of loading combinations during the nowadays designing is possible because of modern hardware and advance software $[6,12$, 13]. Generally, the design codes (for example, EN 1990) require to calculate all relevant design situations. In practice, such detailed analysis is not always made. Big safety factors partially cover the created errors in rough calculations.

\section{Storehouse bearing structures}

\subsection{Initial data, assumptions}

An idea of a detailed investigation appeared during the technical examination of a structural project of a storage building of bulk materials, designed in 2012 and later built on the territory of the seaport of Klaipeda (Fig. 4).

The foundation plate and walls of this storage facility were made of monolithic reinforcement concrete. For technological reasons of the maintenance, the storage volume is divided by using stationary internal walls in sections I, II, III, IV of different dimensions: $36 \times 36,36 \times 30$, $36 \times 30$ and $36 \times 24 \mathrm{~m}$ (Fig. 5). The storage building is covered by a roof of the profiled sheeting on light trussed steel frames, arranged by $6 \mathrm{~m}$ step (Fig. 6). The walls have notches of $0.40 \mathrm{~m}$ wide and $1.95 \mathrm{~m}$ high for steel frames of the roof. 


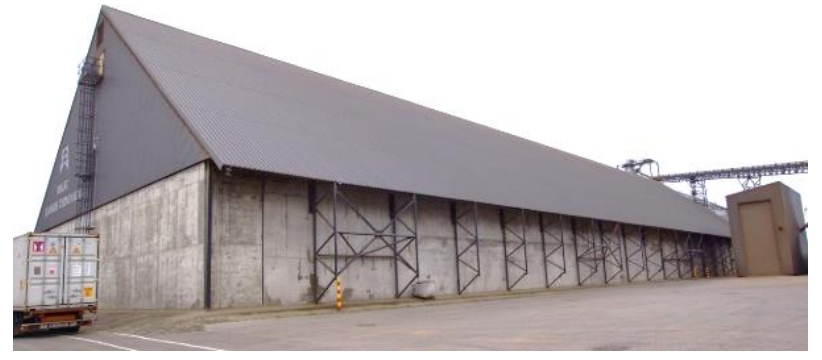

Fig 4 An outside view of the storage facility

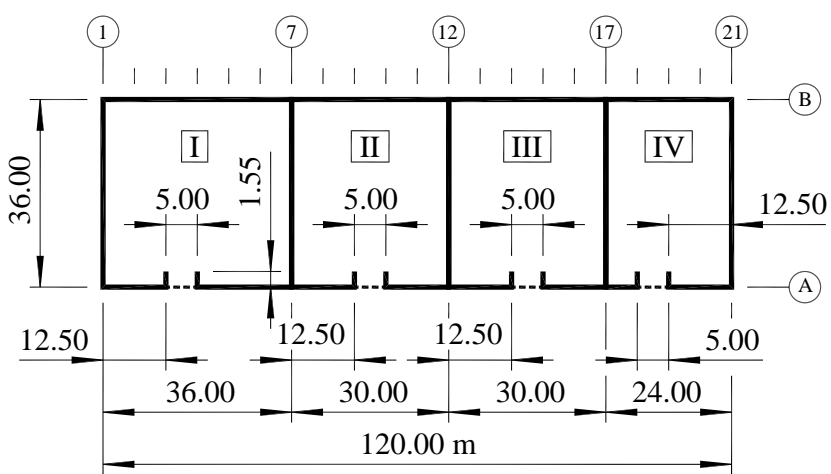

Fig. 5 The plan of location and dimensions of technological sections of the storage facility

In Lithuania loads of storage facilities are designed according valid national regulations (STR 2.05.04:2003 "Actions and Loads" etc.) or Eurocodes (LST EN 1991 "Actions on Structures" etc.), adapted by national annexes. For the storage facility the class of consequences is CC2, the class of reliability - RC2, the operation term - 50 years (STR 2.05.03:2003, LST EN 1990). According to the current RSN 156-94 (climatology for civil engineering) air temperature norms are: average annual $+7.0^{\circ} \mathrm{C}$; absolute minimum $-33.4{ }^{\circ} \mathrm{C}$; absolute maximum $+34.0{ }^{\circ} \mathrm{C}$. The maximum depth of soil freezing is $1.08 \mathrm{~m}$. The storage volume is unheated.

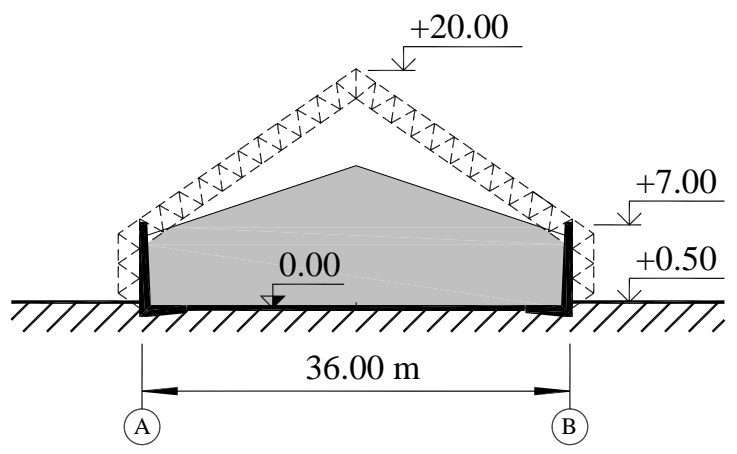

Fig. 6 A principal section of the storage facility

The top layer of the ground of $1 \mathrm{~m}$ thickness was technically compacted. Drainage was made around the perimeter of facility foundations. Considered the geological situation at the construction site, the designers decided to apply the foundation plate without piles, on which reinforcement concrete walls of the storage facility and steel columns of the roof frames are supported.

The foundation plate of the storage facility is divided along the internal outline of each technological sector by deformation seams (Fig. 7). Only vertically directed shear forces are carried through the deformation seam on the ground plate. The stiffness of such seam is set by steel bars of diameter $20 \mathrm{~mm}$ every $0.40 \mathrm{~m}$. The thickness of the inside floor-plate of reinforcement concrete in each sector is defined $0.20 \mathrm{~m}$. The reinforcement concrete foundation plate of variable thickness from 0.20 to $0.50 \mathrm{~m}$ is designed inside at the external walls (Fig. 8) and around the internal walls of the storage facility. Deformation seams in the external and internal walls of reinforcement concrete are also provided. These seams only carry horizontally directed transversal forces.

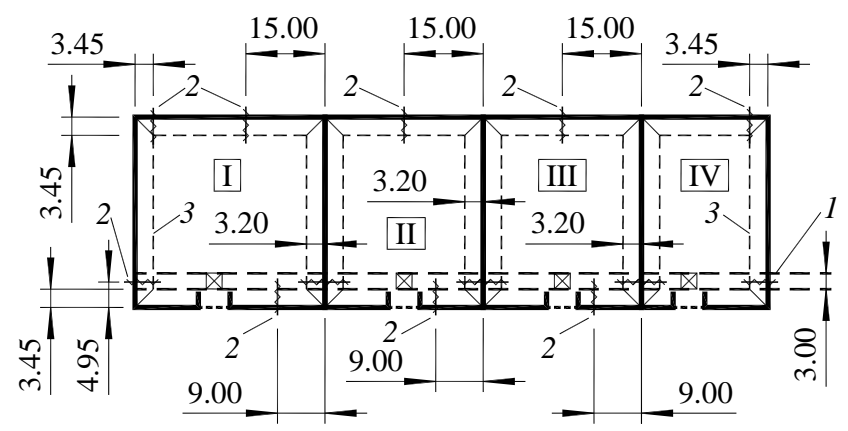

Fig. 7 Location of deformation seams of storage facility: 1 - underground tunnel with a conveyor; 2 - vertical seam on wall and foundation plate; 3 - seam between contour plate and inside plate

The external and internal bearing walls with the contour foundation plate are rigidly jointed. The reinforcement concrete walls are of $7.00 \mathrm{~m}$ height. They are of following variable thickness: $0.50 \mathrm{~m}$ at the bottom and $0.20 \mathrm{~m}$ at the top. The class of concrete is accepted C20/25, Young's modulus - $30 \mathrm{GPa}$, the shear modulus $12 \mathrm{GPa}$, Poisson's ratio -0.20 , reinforcement class $-\mathrm{S} 400$. For the cracking calculation depending on diameters of reinforcement bars, in the horizontal direction the diameter of $20 \mathrm{~mm}$ was set, for vertical bars $-10 \mathrm{~mm}$. Allowable crack width $0.3 \mathrm{~mm}$ was defined from the design codes. The distance from the wall surface to the centre of reinforcement was set of $50 \mathrm{~mm}$, the same - for the foundation plate. The roof frames in comparison with reinforcement concrete sectors have much lower stiffness. Primary calculations [8] showed, that in our case the influence of the steel frame in fact is insignificant, not valuable for the walls and foundations, therefore it was not considered by final calculations. The ground level outside the facility is about $0.50 \mathrm{~m}$. It also is insignificant in the structural analysis.

When the calculation scheme was created, the following loads were taken: volumetric weight of reinforcement concrete $-25 \mathrm{kN} / \mathrm{m}^{3}$; of steel $-77 \mathrm{kN} / \mathrm{m}^{3}$; loads from stored product (Fig. 8). Climatic actions and workloads of transport in the storage facility are negligible. The useful storage area of the whole facility is 4.3 thous. $\mathrm{m}^{2}$, maximal volume of stored bulk materials is 34 thous. $\mathrm{m}^{3}$.

The main assumptions, which have accepted in the perform analysis of the reinforcement concrete bearing structures of the storage facility:

- $\quad$ the same bulk material is considered for all loadings;

- movement ways of transport, when loading or unloading the facility, are not considered;

- $\quad$ stored product is homogeneous, the same density $500-850 \mathrm{~kg} / \mathrm{m}^{3}$, freewheeling angle is $20-50^{\circ}$;

- loading and deformation of the internal floor plate, 
separated by deformation seams, does not affect the calculations of walls;

- the linear elastic analysis of reinforcement concrete is made, after that cracking analysis is performed;

- $\quad$ no dynamic effects;

- $\quad$ any influence of changes of humidity and temperature of stored bulk materials;

- $\quad$ climate temperature effects do not impact the facility;

- $\quad$ friction forces between stored bulk product and walls or floor plates do not act;

- the load on the walls upwardly is distributed according to the triangular principle;

- $\quad$ wind and snow do not directly impact reinforcement concrete structures because in our case are insignificant, as the primary calculation showed [8];

- the results of the calculation of each loading in combinations are integrated applying the principle of superposition;

- $\quad$ soil settlement, earthquake, accidental impacts are not considered;

- $\quad$ no concentrated loads.

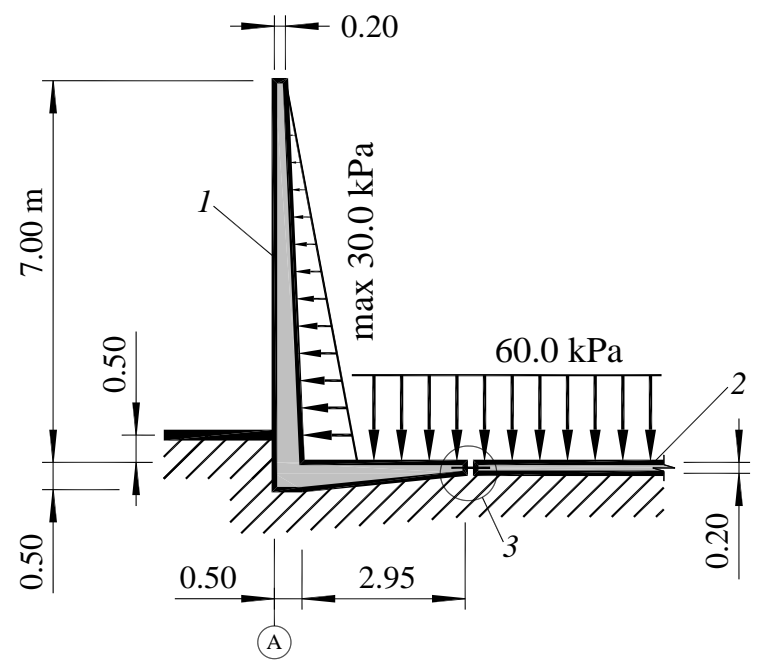

Fig. 8 A principal section of the external wall and foundation plate of the storage facility: 1 - wall; 2 - floor; 3 - deformation seam

In our investigation, the storage facility of bulk materials has been modelled by the FEM. The calculation scheme of the storage facility is composed of: elastically deformable ground base; reinforcement concrete walls on the foundation plate; dead and live loads; combinations of loadings. Two-dimensional plate conventional 4-nodes FE has been chosen for the modelling of the walls and foundation plate. Main step of the FE grid for the walls and foundation plates in both directions is set $0.500 \mathrm{~m}$. The model consists of $33644 \mathrm{FE}$ and 20808 nodes, in total - 123306 degrees of freedom. According to Eurocode 1 the safety factor for dead loads has been defined 1.35, for live loads 1.50. The reinforcement has been calculated by design requirements for strength and resistance to cracking.

\subsection{Combinations for commonly considered loadings}

When loadings of bulk materials for such storage facility are being created by designers, extreme load values are commonly being taken into account (Fig. 9).
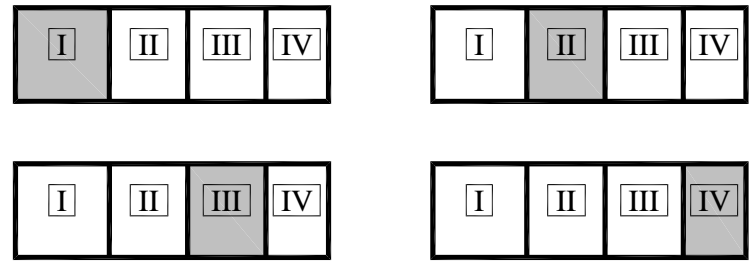

Fig. 9 Prime ordinary loadings

Considering separately the loadings of sectors I, II, III, IV, the initial loadings from 1 to 4 are firstly presented (Table 2). Next, other possible combinations are created. The total number of combinations is $2^{4}=16$.

Table 2

Combinations for ordinary loadings of storage sectors

\begin{tabular}{|c|c|c|c|c|c|}
\hline \multirow{2}{*}{$\begin{array}{c}\text { Combination } \\
\text { No. }\end{array}$} & \multicolumn{4}{|c|}{ Sector No. } & \\
\hline & I & II & III & IV & \\
\hline 1 & 1,50 & & & & \multirow{4}{*}{ 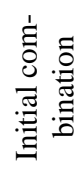 } \\
\hline 2 & & 1,50 & & & \\
\hline 3 & & & 1,50 & & \\
\hline 4 & & & & 1,50 & \\
\hline 5 & 1,50 & 1,50 & & & \multirow{11}{*}{ 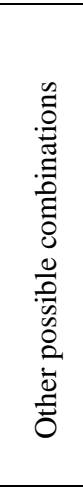 } \\
\hline 6 & 1,50 & & 1,50 & & \\
\hline 7 & 1,50 & & & 1,50 & \\
\hline 8 & & 1,50 & 1,50 & & \\
\hline 9 & & 1,50 & & 1,50 & \\
\hline 10 & & & 1,50 & 1,50 & \\
\hline 11 & 1,50 & 1,50 & 1,50 & & \\
\hline 12 & 1,50 & 1,50 & & 1,50 & \\
\hline 13 & 1,5 & & 1,50 & 1,50 & \\
\hline 14 & & 1,50 & 1,50 & 1,50 & \\
\hline 15 & 1,50 & 1,50 & 1,50 & 1,50 & \\
\hline 16 & & & & & \\
\hline
\end{tabular}

A deformed shape during the initial loadings is expressed in the form " $\mathrm{C}$ " for each wall of the loaded sector. This form is approximately symmetrical respect to both axes in the plan (Fig. 10).

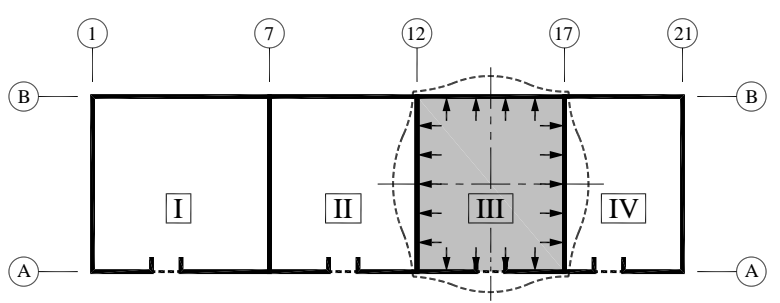

a

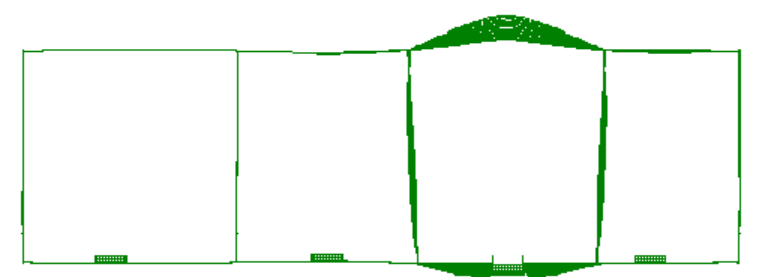

b

Fig. 10 Deformation of full filling storage sector III: $a$ - schematically; $b$ - from FEM software 
Deformation seams and the tunnel under the storage facility are concentrators, which exacerbate the influence of various combinations of loadings on the walls. The influence of openings for gates in the bearing walls and notches for steel frames are also significant.

When the storage facility is operating in market conditions, sometimes it is necessary to place a bulk product of different customers in one sector. In case of dimensions about $30 \mathrm{~m}$ in plan and height of $7 \mathrm{~m}$, such decision is technologically possible. Additional mobile internal walls are used for the separating one bulk material from other (Fig. 11). Certainly, the efficiently of such sector usage is decreases, nevertheless in practice such cases are quite frequent.

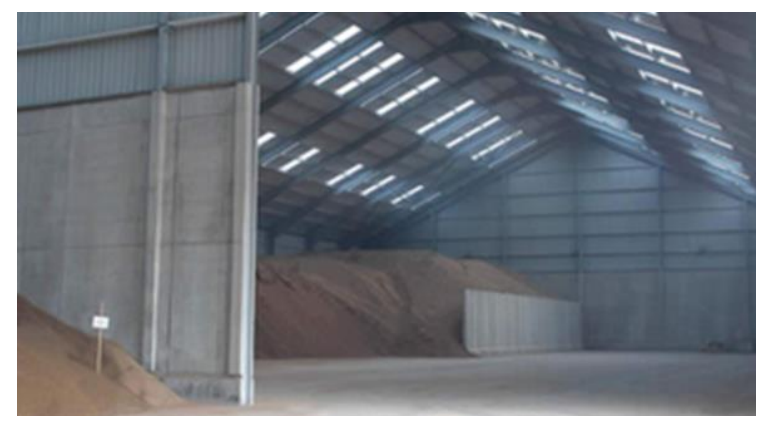

Fig. 11 An internal mobile wall inside a sector

Thus, alternative loadings have been created for the storage facility, based on expected situations. Generally, many partial fillings of each sector are possible: $3 / 5$, $5 / 9,7 / 8$ or others. In this research, we have considered an elementary part $1 / 4$. When an asymmetrical (relative to orthogonal axes of a loaded section) stress/strain state appears, shear forces are significant. So, deformation shape "S" of each wall will be obliquely symmetrical (Fig. 12). Each of four sectors can be filled by $1 / 4$ in any order: $1 / 4$; $2 / 4 ; 3 / 4 ; 4 / 4$. If $1 / 4$ of each of sectors can be filled, we have 16 initial loadings (Fig. 13). In total, it is $2^{16}=65536$ various possible combinations. Of course, the increase in the number of calculations is significant, but these calculations are done by computer.

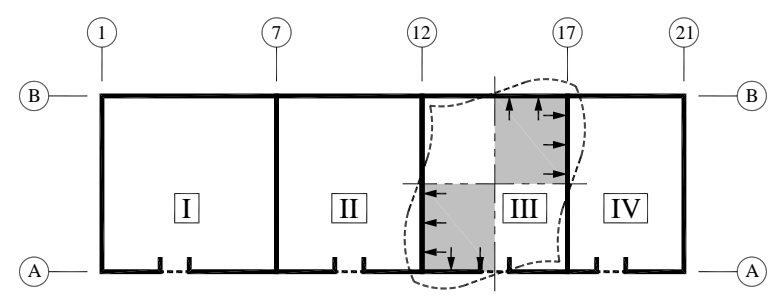

a

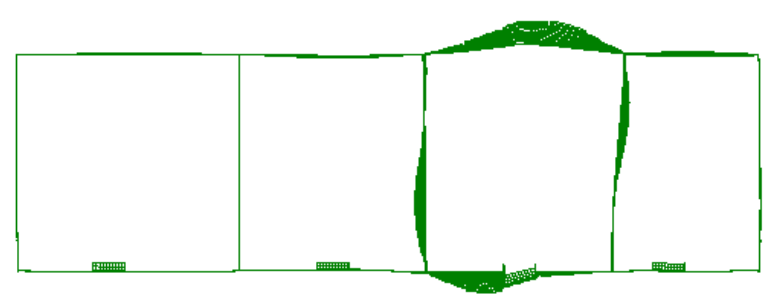

b

Fig. 12 Deformation of partially filling sector III: $a$ - schematically; $b$ - from FEM software 3.3. Custom combinations of loadings
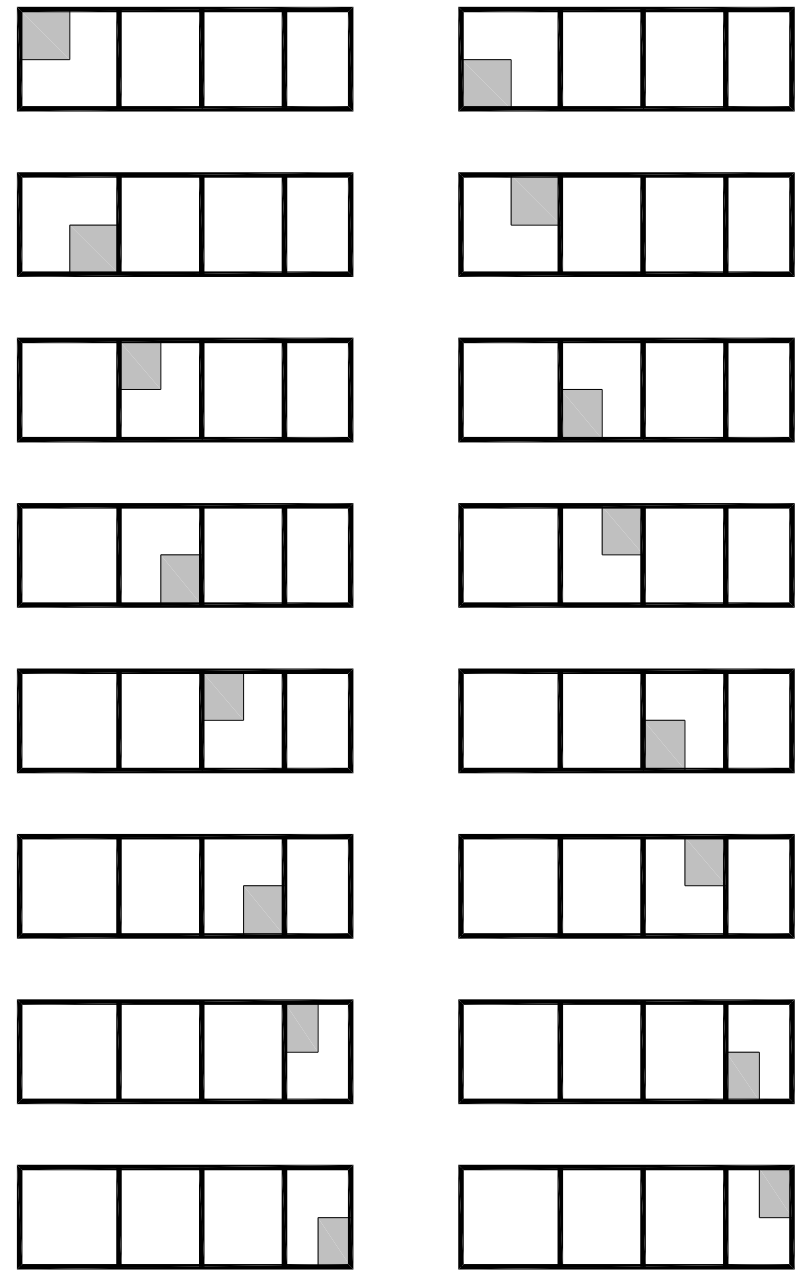

Fig. 13 Prime 16 loadings by $1 / 4$ of any sector

The influence of deformation seams is important enough, because on such lines the axial forces and bending moments disappear. Deformed seams are located asymmetrically - it generates deviations as well as distortions of any filled sector from geometrically ideal deformation shape. So, the shear acts on the structure.

\subsection{Comparison of calculation results}

The calculation results for commonly accepted loads are discussed below in comparison with loads, when storage facility can be partially filled. If one of the sectors is diagonally loaded, a deformation shape in another in comparison with full loaded one and other cross sections are extremely impacted. According to theories of the strength of the reinforcement concrete [14-17], the influence of the shear effect in some cases can be more dangerous than the bending one. Finally, it is important to correctly determine, what reinforcement should be applied for the foundation plate and walls of the storage facility.

For the checking and fixing of specific values of the stress state, 7 points were selected (Fig. 14) at the bottom of the external and internal walls of the storage facility, where the structure is subjected to the bending and horizontal force. Values from the indicated points have been taken from ordinary calculations (Fig. 9) and equated to 1, later - taken from the detailed calculations (Fig. 13). The results have been compared and expressed by relative manner (Table 3). 
The results of the custom calculation relative to the ordinary calculation

\begin{tabular}{|c|c|c|c|c|c|c|c|c|}
\hline \multirow{2}{*}{\multicolumn{2}{|c|}{ Parameter for comparison }} & \multicolumn{7}{|c|}{ The control points on the calculation scheme (Fig. 14) } \\
\hline & & \multirow{2}{*}{$\begin{array}{c}" 1 " \\
1.469\end{array}$} & \multirow{2}{*}{$\begin{array}{c}\text { "2" } \\
1.526\end{array}$} & \multirow{2}{*}{$\begin{array}{c}3 " \\
1.166\end{array}$} & \multirow{2}{*}{$\begin{array}{c}\text { "4" } \\
1.096\end{array}$} & \multirow{2}{*}{$\begin{array}{c}5 " \\
0.998\end{array}$} & \multirow{2}{*}{$\begin{array}{c}\text { "6" } \\
1.774\end{array}$} & \multirow{2}{*}{$\begin{array}{l}7 " 7 " \\
1.012 \\
\end{array}$} \\
\hline & $\min$ & & & & & & & \\
\hline Axial force $N_{x x}$ & $\max$ & 2.009 & 2.394 & 1.038 & 1.011 & 1.003 & 5.545 & 0.587 \\
\hline \multirow{2}{*}{ Moment $M_{x x}$} & $\min$ & 1.151 & 1.086 & 0.955 & 0.981 & 1.008 & 1.589 & 0.718 \\
\hline & $\max$ & 1.220 & 1.109 & 0.957 & 0.982 & 1.008 & 1.210 & 1.008 \\
\hline \multirow{2}{*}{ Moment $M_{y y}$} & $\min$ & 1.192 & 1.224 & 1.057 & 1.010 & 1.021 & 1.804 & $\begin{array}{c}- \\
0.130\end{array}$ \\
\hline & $\max$ & 1.365 & 1.410 & 1.057 & 1.010 & 1.021 & 1.158 & 1.022 \\
\hline \multirow{2}{*}{ Moment $M_{x y}$} & $\min$ & 0.844 & 1.106 & 1.022 & 1.030 & 1.592 & -0.193 & 0.829 \\
\hline & $\max$ & 1.103 & 0.746 & 1.024 & 1.031 & 1.605 & 1.377 & 1.038 \\
\hline \multirow{2}{*}{ Bottom reinforcement } & $X$ & 1.462 & 1.517 & 1.718 & 1.036 & 1.096 & 1.400 & 1.000 \\
\hline & $Y$ & 2.187 & 1.650 & 1.621 & 1.036 & 1.063 & 1.327 & 1.033 \\
\hline \multirow{2}{*}{ Top reinforcement } & $X$ & 1.615 & 1.531 & 1.713 & 1.024 & 1.100 & 1.658 & 1.175 \\
\hline & $Y$ & 0.933 & 0.981 & 1.624 & 1.043 & 1.064 & 1.000 & 1.964 \\
\hline \multirow{2}{*}{ Intensity of reinforcement } & $X$ & 1.543 & 1.523 & 1.708 & 1.026 & 1.099 & 1.486 & 1.135 \\
\hline & $Y$ & 1.143 & 1.149 & 1.617 & 1.039 & 1.063 & 1.263 & 1.187 \\
\hline
\end{tabular}

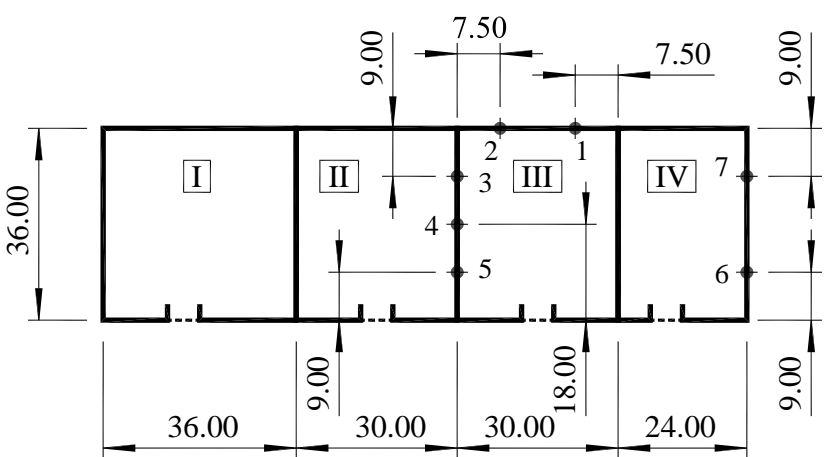

Fig. 14 Numbers and location of the control points

The comparison of the horizontally directed axial forces $N_{x x}$ at the level of the joint between the wall and foundation plate showed, that to external walls (points " 1 ", "2" and "6", "7") the values can even increase twice, for the internal walls (points " 3 ", " 4 ", "5") - maximum only by $+16.6 \%$. The bending moment $M_{x x}$, which is acting in the horizontal plane of the external walls, can increase by $+58.9 \%$, to the internal ones - only by $+0.8 \%$. Moment $M_{y y}$ in the external walls: by $+80.4 \%$, internal - by $+5.7 \%$.

The comparison of the reinforcement results at the control points showed that cross-sectional area of reinforcement bars can increase up to 2 times in both directions of the external walls, for internal ones - by $+71.8 \%$. It is actually for the foundation plate also. Of course, the reinforcement intensity increase significantly too, sometimes by $+70.8 \%$.

As we can see, some results are less than 1 (Table 3). It is because the real calculation conditions have been used, in which there are values near 0. For example, the result 0.718 for $M_{x x}$ at point " 7 " is obtained by follows:

$$
\frac{M_{x x, \text { ordinary }}}{M_{x x, \text { partially }}}=\frac{1.854 \mathrm{kNm} / \mathrm{m}}{2.582 \mathrm{kNm} / \mathrm{m}}=0.718 \text {. }
$$

Such numerical errors do not influence the general mechanical state of the wall and foundation. Some comparison results have been obtained with the minus sign. So, custom calculations have shown the internal forces with opposite sign. This is typically for values close to zero.

The designing of the reinforcement was carried out in accordance with the design codes and mainly depended on the strength and crack resistance of reinforcement concrete, so both stress and strain states of the structure were considered. The comparison of the so expressed and so generalized results is the most important for engineering practice. From the mathematical point of view, conditional optimization (rationalisation) of the solutions reduces the number of combinations.

The distribution of the reinforcement intensity (as a percentage of the cross-sectional area) in the external wall of the sector III on the axis "B", axes from " 12 " to "17", of the storage facility in both calculations are slightly different (Fig. 15). During the custom calculations the vertical ( $Y$-direction) and horizontal ( $X$-direction) reinforcement in the wall is more intensive and distribution area is more expanded. The distribution area with the allowable cracking width $0.3 \mathrm{~mm}$ indicates, that during the custom calculation the cracking area is wider than by the ordinary one (Fig. 15).

Of course, when the calculations are made on a real construction, a number of engineering assumptions have to made, which certainly affect the final results, namely:

- hypotheses in the theory of the reinforcement concrete and regulations in the design codes $[1-6,14,15$, 17];

- a methodology for selecting a combination of internal forces on basis of strength criteria for cross-sectional points and for structural members $[6,12]$;

- $\quad$ in this study an identical consideration of small and high values of internal forces;

- consideration in this study of only extreme values of internal forces and reinforcement;

- $\quad$ limiting the investigations to only 7 control points, i. e. $7 \mathrm{FE}$, on the whole facility.

As the combinations of loadings have been created only for the internal forces by the engineering software, it is not possible to compare the general displacements. However, strains of reinforcement concrete have been limited by choosing of appropriate cross-sectional areas for reinforcement bars. So, a distortion of the wall and founda- 
tion plates has been indirectly used in our investigations. In general, the research shows, that the question of exact solu- tion of the load distribution for port storage facilities is really important.

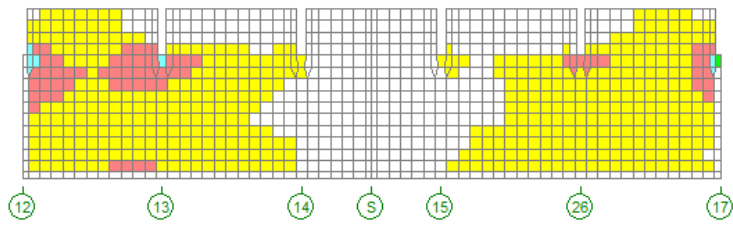

a

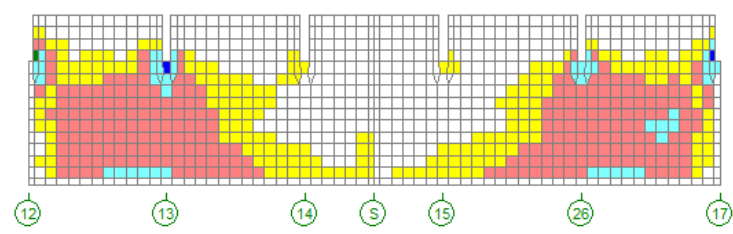

d

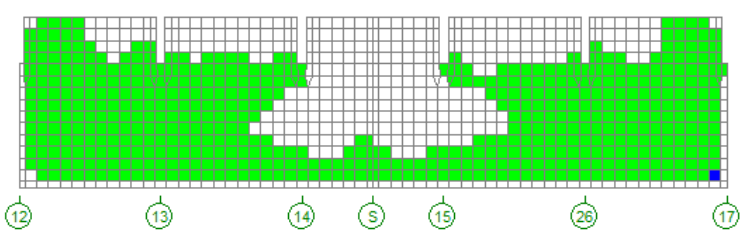

g

\begin{tabular}{|c|c|c|}
\hline$\square$ & 0,02 & 0,5 \\
\hline$\square$ & 0,5 & 1,0 \\
\hline$\square$ & 1,0 & 2,0 \\
\hline$\square$ & 2,0 & 3,0 \\
\hline$\square$ & 3,0 & 4,0 \\
\hline & 4,0 & 4,9 \\
\hline
\end{tabular}

b

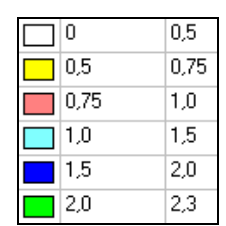

e

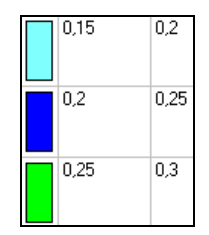

$\mathrm{h}$

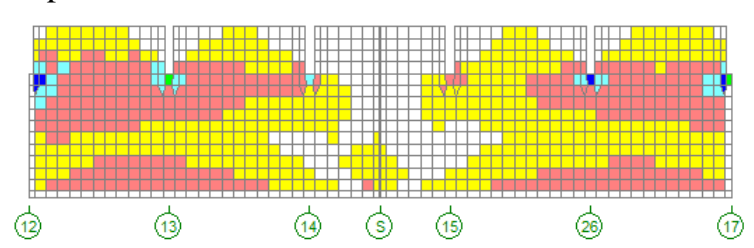

c

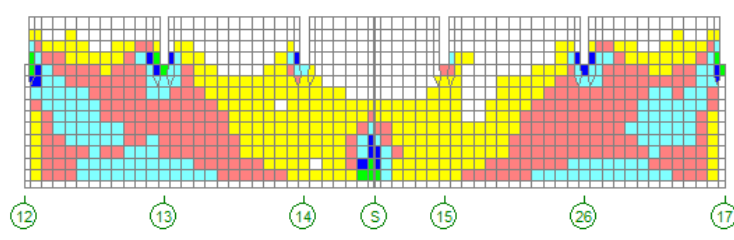

$\mathrm{f}$

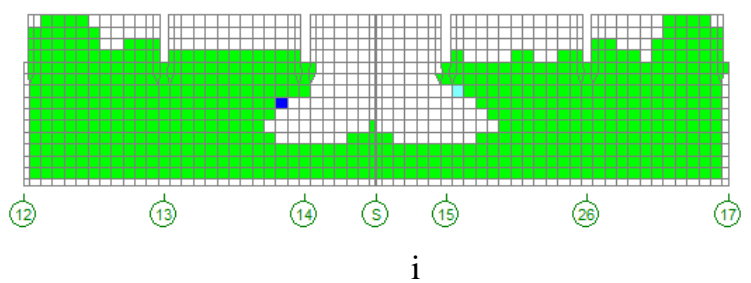

Fig. 15 The reinforcement in external wall of sector III on axis "B", axes from "12" to "17", of storage facility: a - results from ordinary combinations; $\mathrm{b}-X$-axis intensity $(\%)$, scale of colours; $\mathrm{c}$ - custom combinations; $\mathrm{d}$ - results from ordinary combinations; e - $Y$-axis intensity $(\%)$, scale of colours; $\mathrm{f}$ - custom combinations; $\mathrm{g}$ - results from ordinary combinations; $\mathrm{h}$ - crack widths $(\mathrm{mm})$, scale of colours; $\mathrm{i}$ - custom combinations

\section{Conclusions}

On the basis of the presented investigation of the mechanical state of the reinforcement concrete storehouse the following conclusions have been briefly made:

1. The investigation has provided a review of the current engineering situation, a simple example of calculation of a slab with detailed load combinations has been considered, a detailed calculation of custom loading combinations for a port storage facility has compared with an ordinary calculation.

2. The simple test problem of a multi-span reinforcement slab has been considered. It is obtained, that if each of 15 cells are loaded, 32768 combinations are created, and the bending moment in some cross sections of the slab can increase by $+20.7 \%$, reinforcement - by $+22.8 \%$. So, it is important to consider the different loadings for each of cells.

3. Deformation seams and the underground tunnel, being a kind of concentrators, exacerbate the effect of various load combinations for reinforcement walls and foundation plate of the storage facility. Also the influence of large gate openings and vertical cutouts is significant.

4. When bending moments from ordinary used load combinations (when storage sectors are fully filled) are compared with bending moments from custom load combinations (when storage sectors can be partially filled), it is clear, that bending moments, which are acting on the external walls around the vertical axis, can increase by $+58.9 \%$, and around the horizontal one - by $+80.4 \%$. The internal forces on the walls between sectors changed less than in the external contour walls.

5. The comparison of the reinforcement results at 7 control points showed, that cross-sectional area of rein- forcement bars can increase up to 2 times in both directions of the external walls, for internal ones - by $+71.8 \%$. It is also relevant to the foundation plate.

6. When in the designing of the reinforcement the combinations of internal forces are applied (not load combinations), the selection of actual combinations according reinforcement criteria is needed. It is a conditional optimization of the solution. According to the design codes the stress/strain state of reinforcement structural members is evaluated.

7. In calculations of such bulk material storage facilities it is appropriate to apply custom load distribution scheme, because during the maintenance of a storage area some danger situations (not provided in design calculations) can be created. The investigation results can be used for developing of industrial recommendations for the designing of storage facilities.

In general, the research shows, that the question of exact solution of the load distribution for port storage facilities is important enough.

\section{References}

1. Gaythwaite, J. 2016. Design of Marine Facilities: Engineering for Port and Harbour Structures. USA: ASCE. 734 p.

2. Gulvanessian, H.; Formichi, P.; Calgaro, J. A. 2009. Designers' Guide to Eurocode 1: Actions on Buildings. London: Thomas Telford Publ. 285 p.

3. Burgess, I.; Green, A.; Abu, A. 2010. Concise Eurocodes: Loadings on Structures. London: BSI. 109 p.

4. Blight, G. 2005. Assessing Loads on Silos and Other Bulk Storage Structures: Research Applied to Practice. USA: CRC Press. 264 p. 
5. Goodchild, C. H.; Webster, R. M.; Elliott, K. S. 2009. Economic Concrete Frame Elements to Eurocode 2. UK: The Concrete Centre. $181 \mathrm{p}$.

6. SCAD: an integrated system for finite element structural analysis. [Online]. 2019. [Viewed 31 October 2019]. Available from internet: https://scadsoft.com/en/products/scad

7. Samofalov, M.; Žiūkas, A. 2015. Investigation of mechanical state of spatial roof from steel trusses on asymmetric building, Mechanika 21(1): 11-18. http://dx.doi.org/10.5755/j01.mech.21.1.10129.

8. Norvilas, J. 2016. Investigation of Structural Mechanical State of the Port Storage Facility Depending on Load Distribution of Bulk Materials. MSc thesis. Klaipedda University. 50 p. (in Lithuanian)

9. Norvilas, J.; Samofalov, M. 2016. The influence of loos materials load arrangement for mechanical behaviour of port warehouse constructions. XVIII Conf. of Young Scientists of Lithuania "Fundamental Research and Innovations", Lithuania, Klaipeda, 12 May 2016: 79-89. (in Lithuanian)

10. Punmia, B. C.; Jain, As. K.; Jain, Ar. K. 2004. Theory of Structures. New Delhi: Laxmi Publ. Ltd. 648 p.

11. Marti, P. 2013. Theory of Structures: Fundamentals, Framed Structures, Plates and Shells. USA: John Wiley \& Sons. 695 p.

12. Semenov, $\mathbf{S}$. The influence of load locations on the stress/strain state of slabs. [Online]. 2015. [Viewed 5 November 2019]. Available from internet: http://www.myshared.ru/slide/830152/ (in Russian)

13. Reizgevičius, M.; Ustinovičius, L.; Cibulskienė, D.; Kutut, V.; Nazarko, L. 2018. Promoting sustainability through investment in Building Information Modeling (BIM) technologies: a design company perspective. Sustainability. Basel: MDPI AG 10(3): 2-22. http://dx.doi.org/10.3390/su10030600.

14. Punmia, B.C.; Jain, As. K.; Jain, Ar. K. 2007. Limit State Design of Reinforced Concrete. New Delhi: Laxmi Publ. 935 p.

15. Gulvanessian, H.; Beeby, A. W.; Narayanan, R. S. 2009. Designers' Guide to Eurocode 2: Design of Concrete Structures. London: Thomas Telford Publ. 230 p.

16. Gholipour, G.; Zhang, Ch.; Mousavi, A. A. 2019. Loading rate effects on the responses of simply sup- ported RC beams subjected to the combination of impact and blast loads. Engineering Structures 201: 109837.

https://doi.org/10.1016/j.engstruct.2019.109837.

17. Židonis, I. 2019. Curvilinear stress-strain relationship for concrete of EN-2 regulation in the ZI method and the calculation of beam strength, Mechanika 25(5): 341-349. https://doi.org/10.5755/j01.mech.25.5.24453.

M. Samofalov, L. Ustinovičius, A. Šlauteris

LOAD DISTRIBUTION INFLUENCE ON THE

MECHANICAL STATE OF REINFORCEMENT CONCRETE STRUCTURES OF A PORT STORAGE FACILITY

\section{S u m m a r y}

The stress/strain state of reinforcement concrete walls and foundation plate of a storage facility in the seaport of Klaipeda (Lithuania, the EU) is investigated, considering the distribution of loads from stored bulk materials. At the first, a simple test problem has been calculated: reinforcement slab $21 \times 35 \mathrm{~m}$ in plane on 24 columns, which are located by a regular step. During creating the combinations of all 15 possible loadings of each „cell“", increased internal forces and reinforcement results to $+20 \%$ have been obtained. Next, a storage facility of bulk materials with dimensions $36 \times 120 \mathrm{~m}$ in plane has been considered, when expected 16 loadings, 1/4 for each of four storage sectors, has been used in the FEM model. The results of the comparison with the ordinary calculation, in which each of sectors could be fully filled or be empty, have presented. The investigation results can be used for developing of industrial recommendations for the designing of storage facilities.

Keywords: load combinations, load of bulk materials, reinforcement walls, storage facilities, stress/strain state.

Received January 06, 2020 Accepted December 01, 2020 